\title{
RESEÑAS
}

\section{CARMEN BECERRA SUÁREZ, EL MITO DE DON JUAN. MADRID: BIBLIOTECA CASTRO, 2019}

El volumen El mito de don Juan, editado por Carmen Becerra Suárez, reúne las cinco obras escritas en España desde el nacimiento del mito en el barroco hasta las versiones románticas: El burlador de Sevilla y convidado de piedra (Tirso de Molina), La venganza en el sepulcro (Alonso de Córdova y Maldonado), No hay plazo que no se cumpla, ni deuda que no se pague (Antonio de Zamora), El estudiante de Salamanca (José de Espronceda) y Don Juan Tenorio (José Zorrilla). La cuidada edición de estas obras está precedida por una interesantísima introducción crítica en la que la autora examina el devenir del mito, tomando como punto de partida la obra inaugural atribuida al fraile mercedario.

En la Introducción, después de advertir que el estudio de este tipo de mitos -los literarios- posee una complejidad mayor al estar sujetos a continuas reescrituras que originan cambios, más o menos sustanciales, tanto en su función como en su significado, defiende la discutida naturaleza mítica del personaje apoyándose para ello en la presencia activa de la muerte en todas las versiones (reflejo de un sustrato mítico de antiguos cultos a los muertos) y en su paradójica carencia de padre, porque, a pesar de ser un mito histórico de autor conocido (atribuido?), Tirso y su Burlador fueron muy pronto olvidados, pero Don Juan permaneció y permanece en la conciencia colectiva. Las transformaciones que el mito presenta en cada nueva reelaboración son analizadas teniendo en cuenta la época histórica, el pensamiento estético del autor y las diversas influencias y diálogos que cada una mantiene con las precedentes escritas a un lado y otro de nuestras fronteras. Como metodología de análisis se sirve, aunque no solo, de la que, derivada de la antropología estructural, propone Jean Rousset (1978). La estructura del mito se apoya en la presencia de tres invariantes -la muerte, el grupo femenino y el héroe- y las diferentes relaciones que entre ellas se establecen darán lugar a nuevas interpretaciones.

Antes de entrar en el análisis de El burlador de Sevilla, la autora traza un ajustado y preciso contexto de la sociedad en la que nace Don Juan: la situación económica del s. XVII, la mentalidad contrarreformista, la corrupción de la vida de la corte y los valores sobre los que se asienta: el concepto del honor, el papel de la mujer, la fugacidad de la existencia..., dibujando una atmósfera social que explica los claroscuros del barroco. Por otra parte, Becerra pone de relieve el creciente auge del teatro en este siglo (al que contribuye el desarrollo de las ciudades), tanto por la genialidad de los autores, como por el fácil acceso a las representaciones, pero además por las importantes innovaciones técnicas que convertían cada representación en un atractivo y divertido espectáculo visual. 
El burlador de Sevilla (1630?), resumido con eficacia en esta introducción, se estructura en torno a la oposición "burla-huida" y por su relación con el Convidado de piedra y lo ultraterreno. Se trata, según Carmen Becerra, de una obra cargada de dinamismo. La acción, desarrollada con un ritmo vertiginoso, está llena de contrastes y advertencias metafísicas. Comienza in media res y las situaciones y catástrofes in crescendo van definiendo a un don Juan audaz, insolente, joven y de buena posición que engaña (no seduce, como sería de esperar) para burlar a mujeres que confían en sus falsas palabras. El Comendador, padre de una de las ofendidas, desempeña la función social y trascendente de castigar al transgresor y pecador. Las mujeres, colectivo moral y socialmente diverso, son la prueba del delito del héroe. En suma, dice, "en este primer don Juan encontramos el germen del héroe mítico cuya historia y desarrollo posterior conducirá a su madurez". Por tanto, el mito donjuanesco se configura en la obra del fraile mercedario caracterizado con los rasgos de rebeldía, seducción, enfrentamiento a Dios y encuentro con la muerte, rasgos que, a juicio de la autora, son en este drama tirsiano discutibles. Becerra considera que la intencionalidad de esta pieza dramática, su desarrollo y desenlace, las figuras que intervienen en la acción, además de contener una lección moral, encierra una explícita y dura crítica social al evidenciar las miserias sociales y morales de la época.

Tras el análisis de la obra fundacional, Becerra realiza un interesante, somero e ilustrativo repaso de la trayectoria y evolución de don Juan fuera de nuestras fronteras. Su paso por otras plumas lo devolverá a nuestro país con nuevos ropajes, aunque sin perder sus rasgos esenciales que mantienen la estructura mítica. Primero fue acogido por la Commedia dell'Arte italiana y de ahí incorporada al teatro francés, después recala de nuevo en España transformado por las novedades adquiridas en su periplo (destaca el aumento de la comicidad en los escenarios italianos y el envilecimiento del seductor en las piezas francesas).

La venganza en el Sepulcro, atribuida por Arcadio Baquero a Alonso de Córdova y Maldonado (finales del s. XVII), es la segunda obra analizada. Su lectura prueba sin ningún género de dudas que es una imitación directa del Burlador, por lo que mantiene muchos de los elementos y situaciones del don Juan tirsiano (nombres y relaciones entre personajes, doble invitación, condenación final, etc.). Probablemente por su escasa calidad e interés, esta obra de Alonso de Córdova, protagonizada por un don Juan rufianesco, jactancioso y sin escrúpulos (carácter que se mantendrá en la de Zamora), no logró interesar a los estudiosos del donjuanismo que apenas le dedicaron atención.

Se detiene, a continuación, en No hay plazo que no se cumpla, ni deuda que no se pague (1744) tercera de las obras que contiene el volumen. Este drama de Antonio de Zamora incorpora una importante novedad: el "catálogo" de mujeres burladas, lista que no solo desvela las huellas de la influencia italiana (el catálogo es introducido por los comediantes del arte), sino que funciona como un elemento con valor teatral. El carácter de este don Juan nos recuerda al canalla protagonista de la pieza de Alonso de Córdova, muy alejado de la profundidad psicológica del héroe tirsiano. Sus aventuras se muestran como una intensificación cualitativa de delitos que prueban, reiteradamente, su impunidad. Zamora no altera la función del Comendador que también aquí mata a don Juan, sin embargo el desenlace consiente al lector/espectador abrigar dudas respecto a la condena o salvación del alma del pecador, razón por la cual, sostiene Becerra, esta versión supone un precedente para los donjuanes románticos. 
Antes de analizar las versiones románticas del mito, Becerra examina y compendia perfectamente la trayectoria europea del mito con el fin de proporcionar las claves necesarias para la interpretación de las piezas románticas españolas: la ópera de Mozart/Da Ponte, la imprescindible concepción de esta versión musical por Hoffmann (primera versión narrativa), la interpretación que le otorgó Mérimée y los antecedentes legendarios de Miguel de Mañara y el Estudiante Lisardo.

La primera versión romántica española es El estudiante de Salamanca, de José de Espronceda (1836-1840), cuyos precedentes, además del Burlador de Tirso de Molina, son la leyenda de Miguel de Mañara y la obra de Mérimée (Les âmes du Purgatoire). En este largo poema narrativo, descubrimos la aventura de un don Juan rebelde y satánico que visualiza su propio entierro y muere en brazos del esqueleto de doña Elvira. Comparecen, por tanto, los elementos fundamentales de la estructura mítica rodeados de un entorno romántico y sombrío. Se plantean cuestiones como la libertad humana, el enfrentamiento a Dios y el delito o la rebeldía como actos de grandeza individual.

Por último, Becerra analiza el drama de José Zorrilla, Don Juan Tenorio, sin duda la más popular y conocida de todas las versiones donjuanescas. Se trata de un texto en el que se construye a un don Juan alejado del arquetipo sacrílego y libertino creado por sus antecesores. También en esta pieza don Juan visualiza su propio entierro y se mantiene el Comendador con la misma función y simbología, pero introduce un cambio fundamental que afecta al papel de la mujer en la estructura del discurso. Como en las anteriores hay un grupo femenino. Pero además hay una mujer, que no estaba en la lista y que adquiere valor protagónico. Se trata de doña Inés, una novicia de la que don Juan se enamora, y que le corresponde. En el desenlace, presenciamos el arrepentimiento del héroe, su muerte física y la salvación de su alma gracias a la mediación de una mujer enamorada; la divinidad premia su arrepentimiento, su fe en la clemencia de Dios con la salvación eterna. Las fuentes del Tenorio, como el propio Zorrilla afirma, son el Burlador y la obra de Zamora (que Zorrilla atribuye erróneamente a Solís). La salvación del personaje relaciona la obra con el pensamiento romántico y con la doctrina católica que defiende el perdón de los pecados, de tal forma que se moderniza el mito sin alterar sus rasgos esenciales.

Finalmente y a modo de conclusión, Becerra destaca los cambios fundamentales experimentados por el mito desde la obra fundacional, el Burlador, hasta la creación romántica, el Tenorio: don Juan pasa de ser escéptico a creyente, el Dios romántico no es justiciero sino clemente y misericordioso, la mentalidad barroca se transforma en la romántica y la mujer deja de ser un mero elemento funcional para convertirse en la representación de la pureza enviada por la divinidad para salvar el alma del pecador.

Podemos concluir afirmando que el cuidado trabajo de edición de cinco versiones españolas del mito de don Juan, se complementa a la perfección con un estudio profundo y conciso en el que la autora argumenta y proporciona las claves esenciales de la evolución del mito, así como las implicaciones socioculturales asociadas a cada una de estas reescrituras. 